\title{
Sistem Pendukung Keputusan Penentuan Supplier Suku Cadang Mobil Pabrikan Eropa Dalam Konteks Interaksi Manusia Komputer
}

\author{
Agus Aan Jiwa Permana \\ Fakultas Teknik dan Kejuruan \\ Universitas Pendidikan Ganesha \\ Singaraja, Indonesia \\ agus.aan@undiksha.ac.id
}

\author{
Yoga Rizky Alkautsar \\ Jurusan Teknik Informatika \\ AMIK New Media \\ Denpasar, Indonesia \\ datbubs@gmail.com
}

\begin{abstract}
Abstrak-Sistem pendukung keputusan (SPK) yang dikembangkan pada Bengkel StarMotor Bali telah dapat diimplemtasikan dengan baik yang menghasilkan output dalam bentuk alternatif keputusan.

Dalam tahapan selanjutnya, perlu dilakukan uji coba terhadap sistem yang sudah ada dengan memperhatikan aspek ergonomisnya. Pengembang ingin mengetahui respon dari pengguna. Pengguna berhak mendapatkan kenyamanan saat sistem, sehingga perlu disebarkan kuesioner untuk mengetahui respon dari pengguna khususnya montir, kasir, owner dan tester yang dilibatkan dalam uji coba sistem.

Proses uji kelayakan yang dilakukan dengan menyebarkan kuesioner kepada 11 Orang responden yang terdiri dari end user seperti : montir, kasir, owner, dan tester. Berdasarkan kuesioner diperoleh respon $\mathbf{7 5 \%}$ yang berarti sistem yang sudah dikembangkan memiliki nilai ergonomis yang layak
\end{abstract}

Kata kunci-Decision Support System; SPK; Profile Matching; Ergonomis, Uji Kelayakan

\section{PENDAHULUAN}

Sistem pendukung keputusan (SPK) yang dikembangkan pada Bengkel StarMotor Bali telah dapat diimplemtasikan dengan baik yang menghasilkan output dalam bentuk alternatif keputusan. Dengan penerapan metode profile matching (PM) dapat menghasilkan keputusan berdasarkan kriteria yang dimiliki supplier dan kriteria yang diharapkan perusahaan sehingga menghasilkan sebuah perbedaan yang disebut dengan GAP. Setiap kriteria akan memiliki bobot dan kemudian selanjutnya terjadi proses perangkingan untuk melakukan seleksi alternatif terbaik dari sejumlah alternatif yang ada.

Dengan adanya sistem yang menangani pemilihan supplier ini, diharapkan akan dapat memaksimalkan pemilihan supplier secara lebih obyektif khusus dalam pembelian suku cadang. Sehingga proses pemilihan menjadi lebih cepat, dengan data pendukung yang ada menghasilkan alternatif keputusan yang lebih baik. Berdasarkan data observasi dan wawancara, sistem yang sudah dikembangkan memiliki empat kriteria yang digunakan dalam menentukan supplier yaitu harga, kualitas barang, ketepatan waktu pengadaan barang, dan keramahan.

Namun dalam tahapan selanjutnya, perlu dilakukan uji coba terhadap sistem yang sudah ada dengan memperhatikan aspek ergonomisnya. Pengembang ingin mengetahui respon dari pengguna. Pengguna berhak mendapatkan kenyamanan saat sistem, sehingga perlu disebarkan kuesioner untuk mengetahui respon dari pengguna khususnya montir, kasir, owner dan pengguna lain yang juga dilibatkan dalam uji coba sistem.

\section{KAJIAN PUSTAKA}

\section{A. Kuesioner}

Kuesioner biasa dibuat dalam bentuk print out kertas yang berisikan sekumpulan pertanyaan terkait dengan data yang dibutuhkan untuk mengetahui tanggapan dari responden dalam waktu tertentu. Dalam mengisi kuesioner seorang responden harus benar-benar membaca dengan teliti setiap pertanyaan yang diajukan dan memberikan jawaban seobjektif mungkin.

Adapun tujuan dari pengisian kuesioner adalah untuk memperoleh data yang relevan, sesuai dengan yang diharapkan oleh peneliti. Sehingga dalam proses mengumpulkan informasi dari responden yang paling praktis adalah dengan menyebarkan kuesioner. Dalam proses pembuatannya harus melalui proses uji coba terlebih dahulu, sehingga data yang diperoleh adalah valid.

\section{B. Respon}

Respon secara umum dikenal adalah sebuah tanggapan yang diberikan terhadap sesuatu dan dapat diukur. Pada sebuah penelitian, sangat dibutuhkan sebuah respon baik yang berifat positif atau sebaliknya untuk kebutuhan data penelitian.Responden memiliki bentuk respon yang berbeda dengan melalui suatu reaksi seperti : sementara, ragu-ragu, dan hati-hati yang dikenal dengan trial renponse. Terdapat bermacam-macam bentuk tanggapan seperti penerimaan atau penolakan, sikap acuh tak acuh terhadap apa yang disampikan. 
Bentuk respon positif terlihat dari tindakan seperti menerima, mengakui, menyetujui. Sedangkan respon yang negatif dalam bentuk sikap penolakan atau tidak setuju terhadap apa yang disampaikan.

\section{C. $\quad$ Sistem Pendukung Keputusan (Decision Support System)}

Sistem pendukung keputusan yang kemudian dalam istilah asing disingkat DSS merupakan sistem yang dikembangkan berbasis komputer dengan model data tertentu yang digunakan dalam memecahkan masalah yang rumit oleh pengambil keputusan. Menurut [1] DSS adalah sebuah sistem yang dimaksudkan untuk mendukung para pengambil keputusan manajerial dalam situasi keputusan semiterstruktur. Namun dalam penggunaannya, bagi seorang pengambil keputusan dalam hal ini dalam level manajerial hanya bersifat sebagai pendukung, bukan penentu keputusan. Sekali lagi DSS sebagai alat bantu pengambilan keputusan untuk memperluas kapabilitas di level manajerial, bukan untuk menggantikan keputusan yang dibuat secara mutlak.

\section{Konsep Ergonomis}

Berdasarkan Kamus Besar Bahasa Indonesia (KBBI) online istilah Ergonomi diartikan sebagai Pertama : adalah penyerasian antara pekerja, jenis pekerjaan, dan lingkungan dan Kedua : adalah ilmu tentang hubungan di antara manusia, mesin yang digunakan, dan lingkungan kerjanya. Ergonomi adalah ilmu yang menemukan dan mengumpulkan informasi tentang tingkah laku, kemampuan, keterbatasan, dan karakteristik manusia untuk perancangan mesin, peralatan, sistem kerja, dan lingkungan yang produktif, aman, nyaman dan efektif bagi manusia [2].

Dalam desain web sangat diperlukan desain yang baik, untuk menghasilkan web ergonomis. Keterkaitan ilmu desain dengan ilmu ergonomi dapat dilihat seperti Gambar 1. Dalam dunia internet, sebuah situs web yang ergonomis dapat didefinisikan sebagai sebuah web yang mampu untuk merespon secara efektif untuk pengguna dan menyediakan lingkungan nyaman saat browsing [3].

\section{E. Interaksi Manusia dan Komputer}

Interaksi manusia dan komputer ialah disiplin ilmu yang mempelajari suatu hubungan antara manusia serta komputer yang meliputi perancangan, evaluasi, serta implementasi antarmuka pengguna komputer agar mudah digunakan oleh manusia [4]. Definisi dari interaksi manusia dan komputer adalah sebagai berikut :

1. Sekumpulan proses, dialog dan kegiatan yang dilalui pengguna dalam memanfaatkan dan berinteraksi dengan komputer

2. Suatu disiplin ilmu yang menekankan pada aspek desain, evaluasi dan implementasi dari sistem komputer interaktif untuk kegunaan manusia dengan mempertimbangkan fenomena di sekitar manusia itu sendiri.

3. Suatu studi ilmiah tentang masyarakat di dalam lingkungan kerjanya

Berdasarkan paparan diatas, adapun tujuan dari interaksi manusia komputer (IMK), adalah untuk membuat sistem yang lebih dalam hal :

1. Berguna,

2. Fungsional,

3. Aman,

4. Produktif,

5. Efektif,

6. Efisien.

\section{F. Metode Profile Matching}

Menurut [1], metode profile matching atau pencocokan profil adalah metode yang sering sebagai mekanisme dalam pengambilan keputusan dengan mengasumsikan bahwa terdapat tingkat variabel prediktor yang ideal yang harus dipenuhi oleh subyek yang diteliti, bukannya tingkat minimal yang harus dipenuhi atau dilewati.

Metode ini secara umum membandingkan antara nilai data aktual dari suatu profile yang akan dinilai dengan nilai profil yang diharapkan, sehingga dapat diketahui perbedaan kompetensinya (disebut juga gap), semakin kecil gap yang dihasilkan maka bobot nilainya semakin besar.

\section{Proses Pembobotan}

Pada tahap ini, akan ditentukan bobot nilai masingmasing aspek dengan menggunakan bobot nilai yang telah ditentukan bagi masing-masing aspek itu sendiri. Dalam penentuan peringkat pada aspek kapasitas intelektual, sikap kerja dan perilaku untuk jabatan yang sama pada setiap gap, diberikan bobot nilai sesuai dengan Tabel 1 .

TABEL I. BOBOT NILAI GAP

\begin{tabular}{|c|c|c|l|}
\hline No & $\begin{array}{c}\text { Selisih } \\
\text { Gap }\end{array}$ & $\begin{array}{c}\text { Bobot } \\
\text { Nilai }\end{array}$ & Keterangan \\
\hline 1 & 0 & 5 & $\begin{array}{l}\text { Kompetensi sesuai dengan yang } \\
\text { dibutuhkan }\end{array}$ \\
\hline 2 & 1 & 4.5 & $\begin{array}{l}\text { Kompetensi individu kelebihan 1 tingkat } \\
\text { level }\end{array}$ \\
\hline 3 & -1 & 4 & $\begin{array}{l}\text { Kompetensi individu kurang 1 } \\
\text { Tingkat/level }\end{array}$ \\
\hline 4 & 2 & 3.5 & $\begin{array}{l}\text { Kompetensi individu Kelebihan 2 } \\
\text { Tingkat/level }\end{array}$ \\
\hline 5 & -2 & 3 & $\begin{array}{l}\text { Kompetensi individu kurang 2 } \\
\text { Tingkat/level }\end{array}$ \\
\hline 6 & 3 & 2.5 & $\begin{array}{l}\text { Kompetensi individu kelebihan 3 } \\
\text { Tingkat/level }\end{array}$ \\
\hline 7 & -3 & 2 & $\begin{array}{l}\text { Kompetensi individu kurang 3 } \\
\text { Tingkat/level }\end{array}$ \\
\hline 8 & 4 & 1.5 & $\begin{array}{l}\text { Kompetensi individu kelebihan 4 } \\
\text { Tingkat/level }\end{array}$ \\
\hline 9 & -4 & 1 & $\begin{array}{l}\text { Kompetensi individu kurang 4 } \\
\text { Tingkat/level }\end{array}$ \\
\hline
\end{tabular}


Setelah menentukan bobot nilai gap criteria yang dibutuhkan, kemudian tiap kriteria dikelompokan lagi menjadi dua kelompok, yaitu core factor dan secondary factor.

\section{Core Factor}

Core factor merupakan aspek (kompetensi) yang paling menonjol atau paling dibutuhkan oleh suatu keputusan yang diperkirakan dapat menghasilkan kinerja optimal. Perhitungan core factor menggunakan rumus :

$$
\mathrm{NCF}=\frac{\sum N C}{\sum \mathrm{IC}}
$$

Keterangan :

$$
\begin{aligned}
N C F= & \text { nilai rata-rata core factor aspek kapasitas } \\
& \text { intelektual } \\
N C= & \text { jumlah total core factor aspek kapasitas } \\
& \text { intelektual } \\
I C= & \text { jumlah item core factor }
\end{aligned}
$$

\section{Secondary Factor}

Secondary factor adalah item-item selain aspek yang ada pada core factor. Untuk menghitung secondary factor digunakan rumus:

$$
\mathrm{NSF}=\frac{\sum N S}{\sum \mathrm{IS}}
$$

\section{Keterangan :}

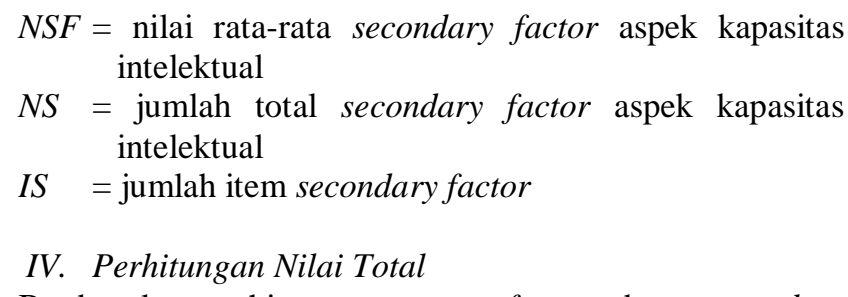

Berdasarkan perhitungan core factor dan secondary factor dari tiap-tiap aspek, kemudian dihitung nilai total dari tiap-tiap aspek yang diperkirakan berpengaruh pada kinerja tiap-tiap profil. Untuk menghitung nila total dari masing- masing aspek, digunakan rumus :

$$
(x) \% \mathrm{NCI}+(x) \% \mathrm{NSI}=N
$$

Keterangan :

$$
\begin{array}{ll}
N C I & =\text { Nilai rata-rata core factor } \\
N S I & =\text { Nilai rata-rata secondary factor }
\end{array}
$$

$N=$ Nilai Total dari aspek- aspek penilaian

$(x) \%=$ Nilai Persen yang dimasukkan

\section{Proses Membuat Ranking}

Hasil akhir dari proses profile matching adalah rangking dari kandidat yang diajukan untuk mengisi suatu jabatan/posisi tertentu. Penentuan mengacu rangking pada hasil perhitungan yang diprosentasekan.

\section{G. Metode Pengumpulan Data}

Dalam pengumpulan data menggunakan tiga cara, yaitu :

1) Wawancara

Metode yang dilakukan dengan cara wawancara langsung dengan Narasumber yang bersangkutan. Kegiatan yang dilakukan adalah melakukan wawancara dengan staff kasir dan owner StarMotor Bali tentang kendala apa yang dialami saat menentukan supplier terbaik.

\section{2) Observasi}

Metode yang digunakan untuk memperoleh data dengan cara mengadakan pengamatan terhadap obyek penelitian dan pencatatan secara sistematis terhadap suatu gagasan yang diselidiki pada penelitian yang mengambil kasus pada bengkel StarMotor Bali.

\section{3) Kuesioner}

Metode ini dilakukan dengan membuat form pertanyaan terkait dengan sifat ergonomis sistem. Setelah form dibuat, maka dalam proses uji coba selanjutnya dikirim ke beberapa responden untuk mengetahui tanggapannya.

\section{HASIL DAN PEMBAHASAN}

\section{A. Deskripsi Sistem}

Dalam pengembangan sistem, terdapat ilustrasi keadaan awal sebelum terdapat sistem, kemudian permasalahan yang muncul, kemudian solusi yang ditawarkan dengan membuat program DSS. Adapun untuk lebih jelasnya dapat dilihat seperti Gambar 1.

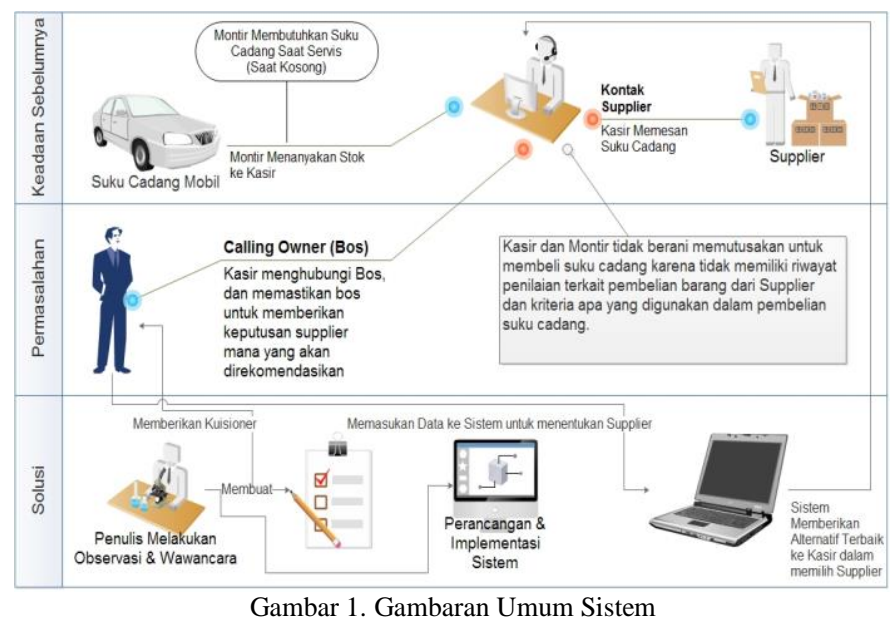




\section{B. Pemodelan Data dan Kriteria}

Pada DSS yang dikembangkan, sangat memerlukan model data. Pemodelan data pada sistem ini menyangkut kriteria, sub kriteria, core factor, dan secondary faktor beserta dengan bobot sesuai tingkat kepentingannya seperti Gambar 2.

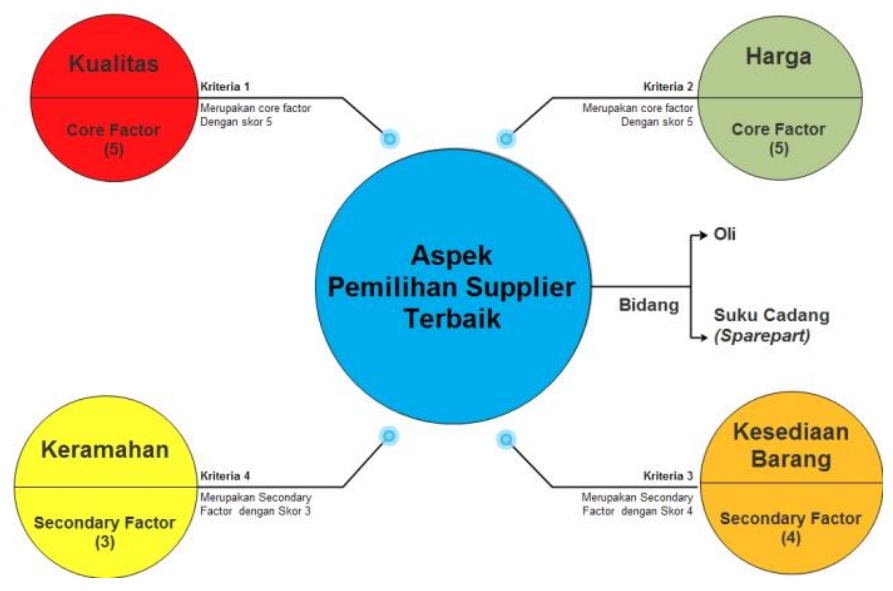

Gambar 2. Model Data Sistem (Kriteria dan Aspek)

\section{Hasil Implementasi Sistem}

\section{1) Halaman Login}

Perbedaan username saat melakukan login dapat berpengaruh pada hak akses system, terdapat dua situasi hak akses yang tergantung kepada status account yang digunakan, yaitu : kasir dan montir dapat dilihat pada Gambar 3.

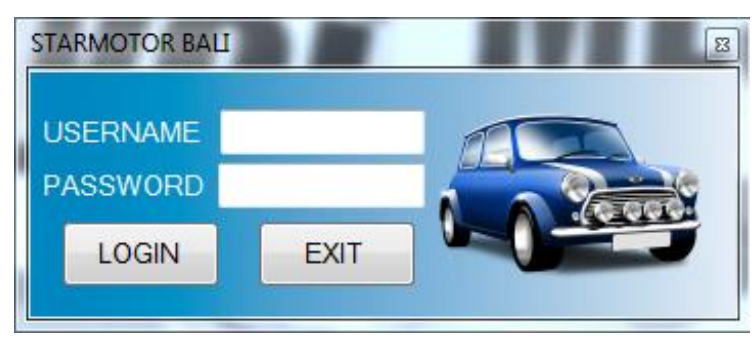

Gambar 3. Halaman Login

\section{2) Halaman Utama}

Gambar 4 merupakan tampilan utama dari sistem yang berisikan menu Data Aspek, Data Kriteria, Data Bidang, Data Supplier, Penilaian, Perhitungan Ranking, Grafik Ranking, Ranking Tersimpan, Logout dan Help. Halaman utama sistem dapat dilihat seperti Gambar 4, dengan data aspek sistem seperti Gambar 5.

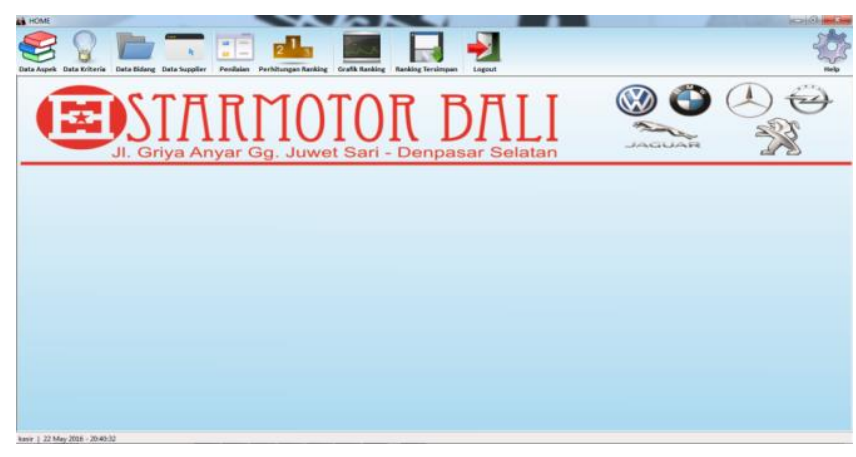

Gambar 4. Halaman Utama

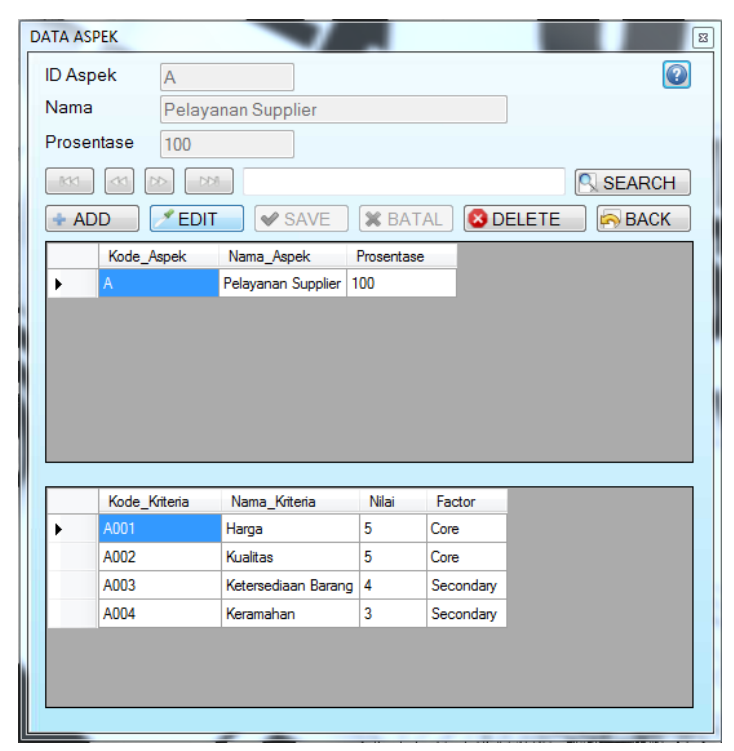

Gambar 5. Data Aspek Sistem

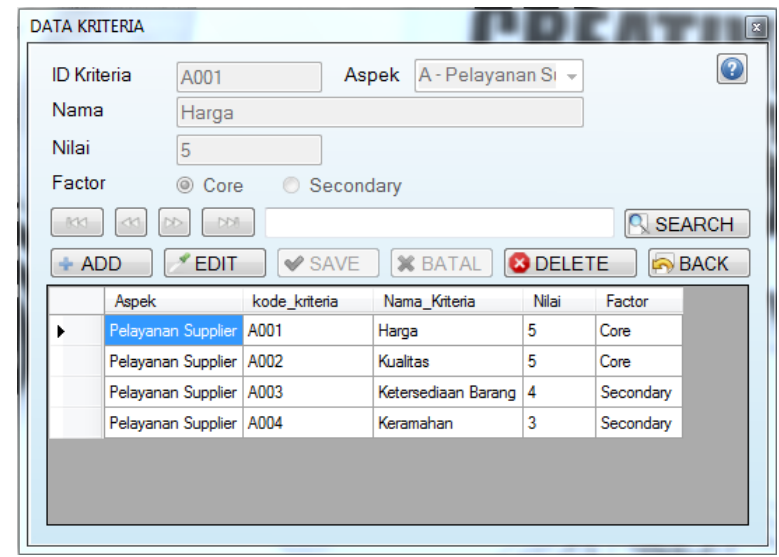

Gambar 7. Manajemen Kriteria

\section{3) Manajemen Kriteria}

Pada halaman data kriteria terdapat beberapa bagian diantaranya ID Kriteria, Nama, Nilai, Faktor dan Aspek. Pada bagian aspek menampilkan data yang sudah terdaftar pada 
database data aspek dalam bentuk dropdown. Adapun lebih jelasnya dapat dilihat pada Gambar 6.

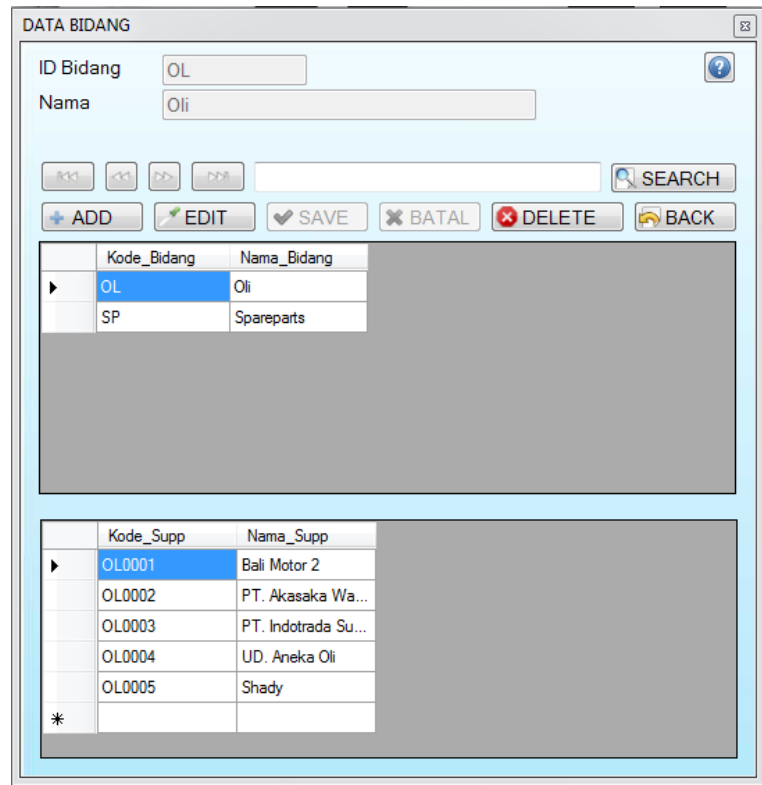

Gambar 7. Halaman Bidang Spesialisasi Supplier

\section{4) Data Bidang Spesialisasi Supplier}

Pada menu di halaman ini dapat digunakan untuk menginput spesialisasi dari supplier. Terdapat dua bagian yaitu ID Bidang dan Nama, untuk lebih jelasnya dapat dilihat seperti Gambar 7.

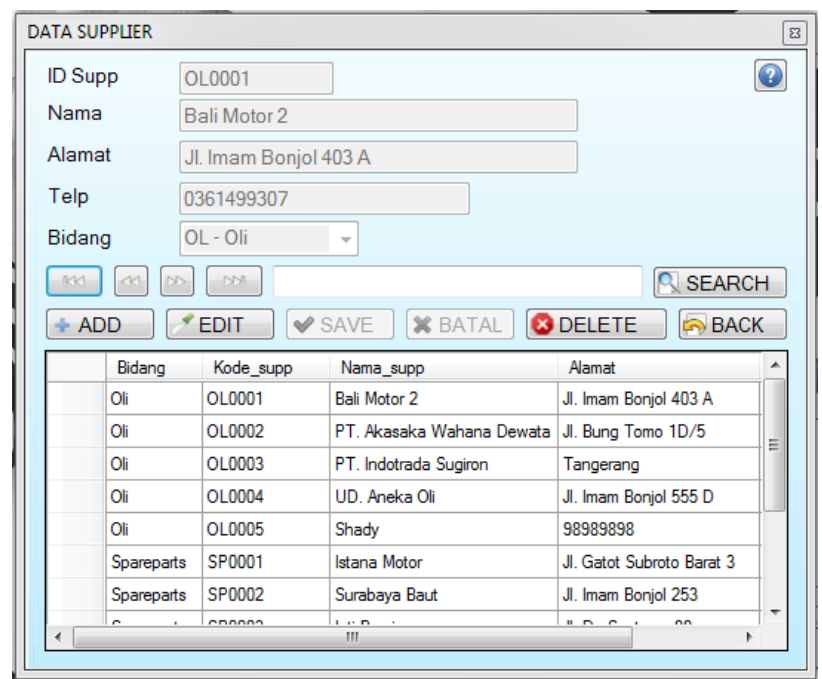

Gambar 8. Manajemen Data Supplier

\section{5) Manajemen Data Supplier}

Halaman ini berisikan ID Supplier, Nama, Alamat, Telp, Bidang. Bidang disini mengambil dari data yang sudah dimasukkan lebih dulu pada menu halaman data bidang (Gambar 8) lebih jelasnya dapat dilihat pada Gambar 8.

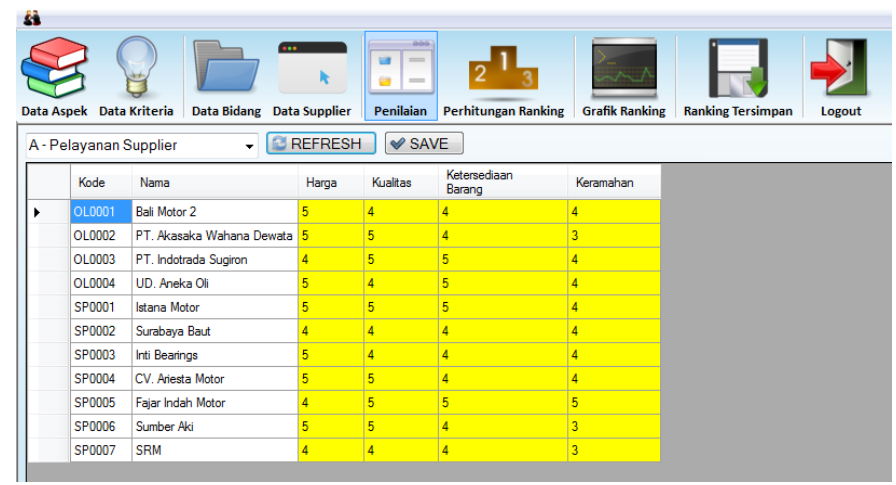

Gambar 9. Penilaian Supplier
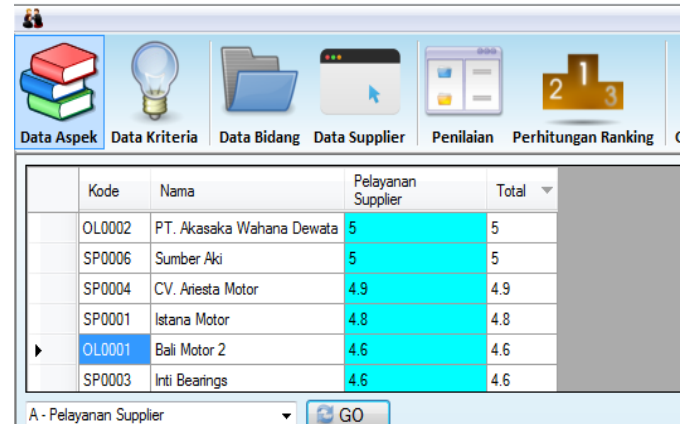

\begin{tabular}{|l|l|l|l}
\hline Nilai Awal & Perhitungan Pemetaan Gap & Pembobotan Nilai Gap & Perhitungan Factor \\
\hline
\end{tabular}

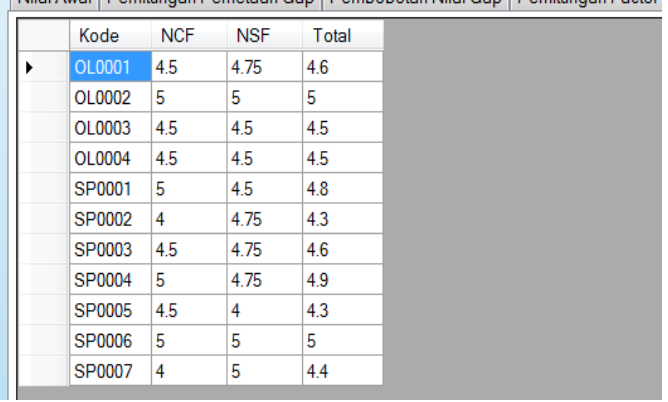

Gambar 10. Hasil Perangkingan

\section{6) Penilaian}

Halaman ini berfungsi untuk memasukkan nilai kriteria untuk setiap supplier dan dipisahkan berdasarkan aspek yang terdaftar dalam sistem, dapat dilihat pada Gambar 9.

7) Perangkingan dan Grafik

Halaman ini merupakan point utama dari perhitungan ranking bagi supplier terbaik seperti pada Gambar 10. Kemudian grafik dari hasil perhitungan ranking dapat dilihat seperti Gambar 11, yang nantinya akan dapat diakses montir 


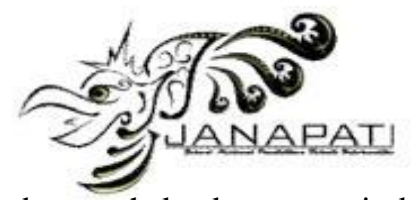

dengan hak akses montir bila kasir sedang tidak berada di tempat.

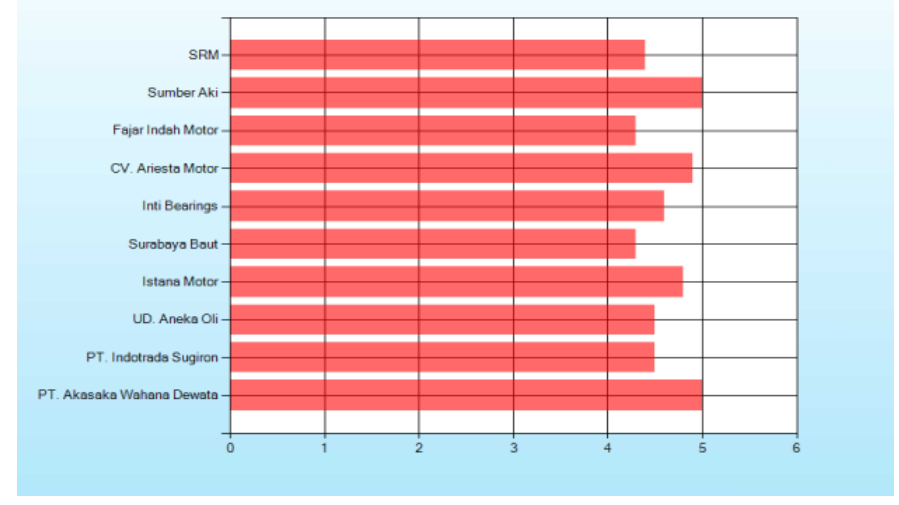

Gambar 11. Tampilan Nilai Dalam Bentuk Grafik

\section{Analisis Hasil}

Berdasarkan hasil implementasi sistem yang telah dilakukan maka dapat diamati bahwa sistem yang dikembangkan sudah mampu memberikan solusi berupa alternatif keputusan dalam bentuk nilai yang dirangking. Supplier dapat dianalisis pelayanannya dengan perhitungan yang diterapkan sesuai rumus dengan metode PM. Dengan data yang bersumber langsung dari pemilik bengkel, tidak diragukan lagi penggunaannya untuk membantu kasir ataupun montir dalam menentukan supplier sesuai dengan kriteria yang ditentukan pada saat kondisi tertentu, terutama saat pemilik sedang ke luar kota atau sedang sibuk di luar kantor.

\section{E. Uji Kelayakan Sistem}

Proses uji kelayakan yang dilakukan dengan menyebarkan kuesioner kepada 11 Orang responden yang terdiri dari end user seperti : montir, kasir, owner, dan tester. Kuesioner berisi enam indikator yang terkait dengan sifat ergonomis sistem seperti :

$$
\begin{array}{ll}
\checkmark & \text { Simplicity } \\
\checkmark & \text { Structuring } \\
\checkmark & \text { Learnability } \\
\checkmark & \text { Satisfaction } \\
\checkmark & \text { Accessibility } \\
\checkmark & \text { Validity }
\end{array}
$$

Kemudian dari enam indikator, dapat dijabarkan lagi menjadi 11 kriteria terkait dengan aplikasi yang ergonomis seperti :

- Kesimpelan desain aplikasi

- Kerapian letak struktur menu

- Kemudahan membaca tulisan menu

- Kemudahan mengakses halaman utama program

- Kemudahan memasukkan data, pertama kali akses

- Kemudahan mencari informasi, pertama kali akses

- Kenyamanan tampilan aplikasi

- Kenyamanan menggunakan aplikasi
p-ISSN 2089-8673 | e-ISSN 2548-4265

Jurnal Nasional Pendidikan Teknik Informatika (JANAPATI)

Volume 5, Nomor 3, Desember 2016

- Kemudahan dalam mengakses informasi

- Kesesuaian data sistem dengan data lapangan

- Kesesuaian alternatif yang ditawarkan sistem

Data yang diperoleh dari responden selanjutnya dicatat dan diproses dengan bantuan aplikasi pengolah angka (Excel) dan menghasilkan nilai dalam bentuk prosentase seperti Tabel II dan grafiknya dapat dilihat pada Gambar 12.

TABEL II. DATA RESPONDEN
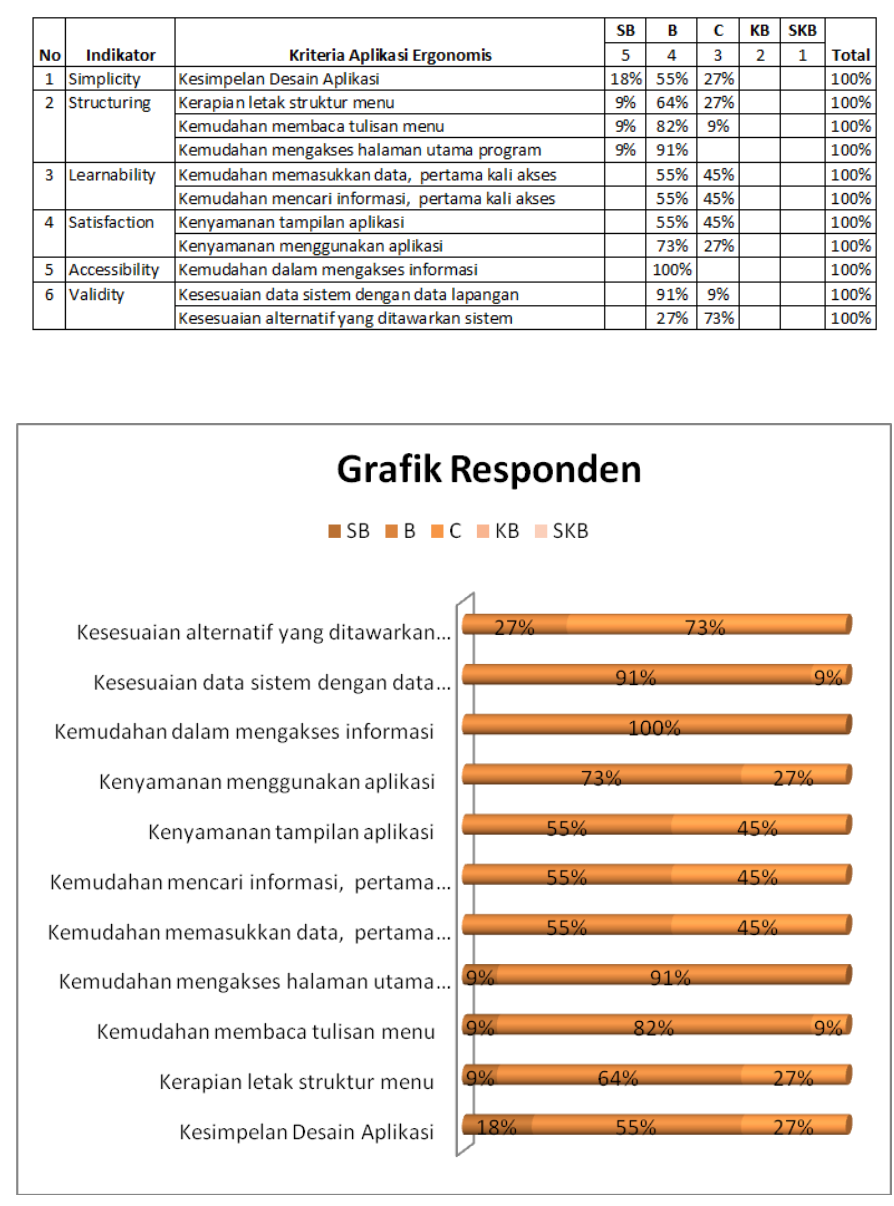

Gambar 12. Grafik Responden Aplikasi Ergonomis

Tabel III. Kategori Kelayakan ( Sumber : [5] )

\begin{tabular}{|c|c|c|}
\hline No & Presentase (\%) & Kategori Kelayakan \\
\hline 1 & $<21 \%$ & Sangat Tidak Layak \\
\hline 2 & $21 \%-40 \%$ & Tidak Layak \\
\hline 3 & $41 \%-60 \%$ & Cukup Layak \\
\hline 4 & $61 \%-80 \%$ & Layak \\
\hline 5 & $81 \%-100 \%$ & Sangat Layak \\
\hline
\end{tabular}

Berdasarkan Tabel III, maka dalam akumulasi data dari lapangan diperoleh hasil bahwa skor maksimal yang diperoleh dari 11 responden diperoleh skor maksimal 55 dengan cara 
mengalikan jumlah responden dengan nilai skor tertinggi (5) menghasilkan, kemudian untuk skor kelayakan diperoleh dengan rumus rerata/maks.

\begin{tabular}{|rl|}
\hline Skor maks : & 55 \\
Skor Rerata : & 41.36 \\
Skor Kelayakan : & $\mathbf{7 5 \%}$ (Layak) \\
\hline
\end{tabular}

\section{PENUTUP}

\section{A. Kesimpulan}

Berdasarkan penelitian yang dilakukan, dapat disimpulkan beberapa hal antara lain :

- Sistem telah mampu dikembangkan dan dapat memberikan alternatif keputusan sebagai solusi dalam permasahalah yang dihadapi.

- Pemilik Bengkel dapat menentukan pembobotan aspek, kriteria hingga penilaian kepada setiap supplier agar memudahkan dan memperjelas perhitungan yang dilakukan kasir

- Berdasarkan kuesioner diperoleh respon $75 \%$ yang berarti sistem yang sudah dikembangkan memiliki nilai ergonomis yang layak.

\section{B. Saran}

Berdasarkan ekseperimen yang telah dilakukan terdapat beberapa hal yang ingin disarankan antara lain :

- Sistem saat ini masih bersifat stand alone, dan dirasa perlu nantinya dapat dikembangkan berbasis web untuk dapat digunakan secara online dengan diterapkan pada bidang lainnya.

- Pada perhitungan rangking, harus dapat di filter jika hanya ingin memproses bidang tertentu saja. Misalkan oli saja atau sparepart saja. Sehingga akan meringankan beban selama komputasi.

- Kriteria dan aspek sewaktu-waktu dapat ditambahkan lagi, sesuai dengan perkembangan di lapangan.

\section{REFERENSI}

[1] Kusrini dkk, 2006, "Sistem Pendukung Keputusan Evaluasi Kinerja Karyawan Untuk Promosi Jabatan" Yogyakarta, STMIK AMIKOM

[2] Wardani, Laksmi Kusuma. 2003, Evaluasi Ergonomi Dalam Perancangan Desain, Dimensi Interior, Vol. 1, No. 1, Juni 2003: $61-73$

[3] Webmastering, 2016, Website Ergonomics, http://ccm.net/contents/777-webmastering-websiteergonomics, diakses 11 April 2016
[4] Setiawan, parta .2015, Pengertian dan Tujuan IMK, http://www.gurupendidikan.com/pengertian-interaksimanusia-komputer-terlengkap/, diakses : 13 April 2016

[5] Ikhsan, H. 2014, BAB III Metodologi Penelitian, http://eprints.uny.ac.id/21857/4/4\%20BAB\%20III\%20075 20244064.pdf, diakses 21 April 2016 